\title{
TTR
}

Traduction, terminologie, re?daction

\section{Translation as a Provider of Models of Sociological Discourse in Nusantara}

\author{
Brian D. Smith
}

Volume 10, numéro 1, 1er semestre 1997

Langues, traduction et post-colonialisme

Languages, Translation and Post-Colonialism

URI : https://id.erudit.org/iderudit/037287ar

DOI : https://doi.org/10.7202/037287ar

Aller au sommaire du numéro

\section{Éditeur(s)}

Association canadienne de traductologie

ISSN

0835-8443 (imprimé)

1708-2188 (numérique)

Découvrir la revue

Citer cet article

Smith, B. D. (1997). Translation as a Provider of Models of Sociological

Discourse in Nusantara. TTR, 10(1), 263-282. https://doi.org/10.7202/037287ar
Résumé de l'article

Apports de la traduction au discours sociologique au Nusantara - La sociologie connaît une croissance rapide en tant que discipline académique et instrument de développement national dans les nations de langue malaise de l'Asie du Sud-Est : le Brunei Darussalam, l'Indonésie et la Malaisie. Les particularités de la terminologie et du discours sociologiques posent des problèmes spécifiques pour les traducteurs de textes sociologiques, qui ont été à l'avant-garde des créations linguistiques en raison de l'usage croissant de manuels en langue nationale.

En Indonésie, où les études supérieures sont, depuis l'indépendance, conduites en indonésien, les premiers textes sociologiques furent traduits du hollandais. Cependant, après le départ des Hollandais, un soutien américain majeur à l'enseignement de la sociologie de la part des États-Unis, a donné lieu, depuis les années 60 , à une nouvelle vague de textes traduits cette fois-ci de l'anglais. En Malaisie, le choix du malais comme langue d'enseignement universitaire a suscité le besoin de traduire les mots-clés anglais. Au Brunei Darussalam, si l'enseignement universitaire se fait en anglais, les étudiants de langue malaise ont ressenti la nécessité de traduire les documents sociologiques pour réussir dans leur apprentissage.

Bien que ces trois pays se soient accordés pour standardiser la terminologie et la morphologie, le langage sociologique est dans une certaine mesure devenu divergent. Pendant ce temps, la pénurie de traducteurs qualifés empêche la production suffisante et adéquate de traductions.

Cet article aborde (1) les notions de " transparence » et « d'invisibilité » dans l'élaboration de textes cibles en langue indonésienne et malaise ainsi que (2) la possibilité de " domestiquer » les concepts et méthodologies et de fournir des textes cibles qui puissent être utilisés tant pour les études que pour la recherche.

Tous droits réservés ( $\mathrm{C}$ TTR: traduction, terminologie, rédaction — Les auteurs, Ce document est protégé par la loi sur le droit d’auteur. L’utilisation des 1997 services d'Érudit (y compris la reproduction) est assujettie à sa politique d'utilisation que vous pouvez consulter en ligne.

https://apropos.erudit.org/fr/usagers/politique-dutilisation/ 


\title{
Translation as a Provider of Models of Sociological Discourse in Nusantara
}

\section{Brian D. Smith}

\begin{abstract}
The social sciences have seen rapid growth both as academic subjects and as instruments of national development in Brunei Darussalam, Indonesia, and Malaysia. The particular nature of social science terminology and discourse has presented special problems for the translator. The increasing dominance of English in the region has compounded these problems.
\end{abstract}

Social science is a broad term which may be applied to many disciplines - anthropology, demography, history, geography, psychology, political science, etc. and "the primary goal of the social sciences is to obtain organised knowledge of social reality" (Schutz, 1970, p. 5). As a group, these disciplines share a common approach to the study of social phenomena, labelling and defining concepts and constructing theories with everyday language. As a result, "in much of the existing literature of the social sciences, words continue to refer to vague conceptions rather than to demarcated concepts" (Sartori, et al., 1975, p. 1). Since it would be impossible to cover translation problems for all the social sciences here, this paper will exemplify these problems in the field of sociology, the core social science. 


\section{Defining Sociology}

The term sociology is said to have been used simultaneously for the first time in 1843 in French (sociologie) by Auguste Comte and in English by a commentator on Comte in Blackwoods Magazine and by John Stuart Mill in Book VI of his Logic. However, though sociology is over 150 years old, sociologists still find it difficult to reach an agreed definition of the term itself. Sociology has a 'hollow frontier' in that although sociological research is grounded in general sociological theory there is also an open ended series of special sociologies. As Eldridge points out, "There is almost no end to the words which complete the phrase 'the sociology of..." (Eldridge, 1980, p. 29). For the purposes of this paper I shall have in mind Giddens' overarching definition. Sociology is "the study of human groups and societies, giving particular attention to the analysis of the industrialized world" (Giddens, 1979, p. 248).

\section{Sociological English}

At the turn of the century sociological writing was blamed for the poor quality of French in the Sorbonne (Lepenies, 1988, p. 52). Many of the pioneer sociologists wrote in languages other than English and thus, as it became established as a discipline, sociology faced problems of translation into English. Since the Second World War, sociology has been dominated by American scholars and American English is now the dominant language of much sociological writing. Thus any translation difficulties are faced almost entirely by other languages into which sociological knowledge needs to be translated from English. This paper focuses on the translation problems faced by Brunei Darussalam, Indonesia and Malaysia in absorbing the discourse and terminology of sociological knowledge from English into their shared national language.

Today there is considerable and continuing concern with the quality of sociological English. For Bolinger "the full riches of jargon are best savoured in the softest of the soft sciences, sociology and its branches" (Bolinger, 1980, p. 127). After detailed analysis Lachenmeyer reached the conclusion that the basic weakness of sociological English was its resemblance to conventional language. As Mayntz and his colleagues point out, it is "everyday language with its undefined concepts, which is the principal source of concepts in sociology" (Mayntz, et al., 
1976, p. 13). In Lachenmeyer's view, sociologists use terms and theoretical statements that are imprecise because they abound in ambiguity, vagueness, opacity and contradiction : terms and theoretical statements discriminate too wide a range of referents, not true references, or logically inconsistent referents. Sociologists often do not deal with observable phenomena but rather with reports about and inferences based on these phenomena. Sociologists also favour definition by example which can give legitimacy to a term of low precision. This scenario is complicated by the fact that terms "are appropriated by technical specialists from lay discourse, new meanings given to them, and these meanings later returned to lay discourse" (Giddens, 1979, p. 248).

Sociologists writing in English see sociological language in various ways. Worsley, for example, divided sociological vocabulary into two types : a) parametric terminology e.g. labelling in situations in a given society; b) concept vocabulary e.g. role, social mobility - lexical items as tools to study society (Worsley, 1970, p. 29). Gould has offered three sub-divisions (Gould, 1963, p. 32), starting from the premise that "amid the variety of empirical studies there has grown up a sense that the study of the subject (sociology) can be secured, to some significant degree, through the development of common theoretical systems resting upon widely applicable sets of concepts", which in practice means "applying sets of fairly standard concepts to the analysis of many different social phenomena". He also accepted a second approach, system-building, which he suggested had resulted, at its best in a valuable prolegomen to theory and at worst a diversionary substitute for it. Gould also saw sociological language in three dimensions :

a) the overlap between general and sociological vocabulary e.g. family is used by both laymen and sociologists both broadly and narrowly "to denote kinship patterns as well as households or household units";

b) the vocabulary of sociological theories and their application to social research;

c) the vocabulary which denotes techniques and methods of social investigation - a specialised set of terms.

\section{Standardisation of Sociological Terminology}

From time to time efforts have been made to standardise the language of sociology by attempting to agree on the meaning of concepts. However 
the burgeoning of new specialisations has led to a compartmentalisation and fragmentation of sociology and sociological theory which has meant that many sociologists cannot easily communicate with others. A "crisis of fragmentation has arisen" - "fragmentation through specialisation and fragmentation through theoretical confrontation" (Johnson, et al., 1984, p. 1). Social scientists seem incapable of achieving the agreement on terminology reached by natural scientists and technologists e.g. the work of the American Society for Testing and Materials (Wright and Strehlow, 1993).

\section{Sociology in Nusantara}

\section{Sociology in Indonesia}

Sociology has a long history as a field of academic study in Indonesia. It was first taught as a subject in the Law College (Rechtshogeschool) founded by the Dutch in Jakarta in 1924, though by 1936 only two Indonesians had taken the course. Until 1939 sociology was taught by Dr. Professor B. Schrieke, who was very much influenced by the German sociologist Max Weber. Two other noted Dutch social scientists, Boeke and Wertheim, likewise taught at the Law College before WWII. The culture and civilization of Indonesia were also taught to Dutch colonial administrators and missionaries as Indology from the 19th century onwards and Indology was in the syllabus of the Faculty of Letters and Philosophy established in Jakarta in 1940, with sociology as one area of study.

Higher education in Dutch ended with the Japanese occupation, but on their return in 1945 the Dutch established a full university in Jakarta, including a Faculty of Law and Social Sciences, which became the University of Indonesia in 1950 following independence. A new institution of higher education, the Balai Pergoeroean Tinggi Gadjah Mada (BPTGM) was established by the Republican Government in Yogyakarta during the independence struggle and the first courses in sociology were taught in 1948 by Indonesian jurists. After independence the BPTGM became Gadjah Mada University, where a Faculty of Social Sciences was set up in 1952 . In 1955 a British social anthropologist, Dr. M. E. Jaspan, was appointed to assist in the development of the Faculty. 
At the University of Indonesia, sociology continued to be taught in the Law Faculty by Dutch teachers until well into the 1950 s and the first sociological texts to be translated into Indonesian were Dutch works. The first Indonesian teacher of sociology at the independent university was Professor Mr. Djokosutono, an eminent nationalist lawyer. A separate Faculty of Social Sciences was not created until 1969 under the direction of Professor Dr. Selo Soemardjan. From the late 1960s American influence became paramount. American scholars came to Indonesia for fieldwork and numbers of Indonesian scholars were sent to the US for postgraduate study. By 1972 there were 100 teachers of sociology and by 1976, 13 Indonesians had received doctorates in sociology. By 1981 sociology was being taught as a degree subject at the four major state universities and at the private Catholic Atma Jaya and Parahyangan Universities. Introductory courses in sociology were also being given at another 22 state universities and at a number of private universities. By 1986,149 teachers of sociology were recorded in 9 universities, including 7 with overseas $\mathrm{PhDs}$ and 26 with indigenous $\mathrm{PhDs}$ (Malo, 1989, p. 218).

The role of the social sciences in national development was recognized early on. Though major government funding was mainly channeled to the field of economics, considerable American support was given to the development of the other social sciences. A landmark study (Geertz, 1971, p. 24) funded by the Ford Foundation in 1971 reviewed needs and proposed the funding of social science research stations attached to provincial universities where selected young Indonesian scholars could develop their research abilities by undertaking practical projects of great value to local communities. On completion of these projects, further training would be given overseas as a prelude to completion of an Indonesian doctorate. Geertz attached particular importance to selecting first-class foreign post-doctoral students with a good knowledge of Indonesia as station leaders :

For the fact is that the social science knowledge to be transmitted is largely commanded by people who do not speak Indonesian - and is contained in books not written in Indonesian - and that knowledge is to be transmitted largely in people whose command of languages other than Indonesian is shaky at best. (Ibid., p. 27)

As a result of Geertz's report, centres were set up with Ford Foundation assistance in Aceh (1974), Ujung Pandang (1975) and Jakarta 
(1976). The Ford Foundation also gave support to the setting up of a Social Science Foundation in 1976 to stimulate research, training, translation and publication.

Sociological research by Indonesians began in the 1950s and until 1965 was mainly oriented towards rural sociology. After 1965, areas of research widened and work was done on political, industrial, religious and urban sociology and the sociology of art. Under the influence of American scholars and postgraduate training in the US, methodologies and textbooks used in Indonesia have become almost entirely American. Numbers of American textbooks have been translated under the auspices of the Social Science Foundation, the privately funded Institute for Economic and Social Research, Education and Information (LP3ES) and Obor, a private foundation, but so far only a handful of texts have been written by Indonesian scholars. Indeed the first major research study by an Indonesian sociologist, Dr. Selo Soemardjan's Social Change in Yogyakarta, published in 1961, was not published in an Indonesian translation until 1981 . Thus university reading lists consist mainly of books written in English, difficult to find in bookshops and university libraries, and prohibitively expensive. Of 109 texts recommended for higher education listed by Malo in 1989, 8 were translations of foreign texts and 25 were original texts by Indonesian authors; the remaining 76 were foreign texts in English (Malo, 1989, pp. 268-273). There has been no significant change in proportions since then. The need for Indonesian texts has remained critical since only a small proportion of Indonesian students can read textbooks in English ${ }^{1}$.

\section{Sociology in Malaysia}

University education came to Malaysia somewhat later than to Indonesia and was initially English-medium. It was not until 1983 that Malay-medium courses became a requirement in Malaysian higher education. Thus sociological writing in Malay is comparatively rare. The National Language and Literature Bureau has made considerable efforts to supply the necessary discourse by terminology creation and translations

${ }^{1}$ See e.g. Evers, (Unpublished), p. 10. 
of selected texts and one or two basic texts written in Malay have been published. However, beyond these, the Malaysian student will have to read in English, and, as government policy is now to allow tertiary tuition in English again, it does seem likely that the use of Malay will be hindered, if not discontinued, in academic writing.

\section{Sociology in Brunei Darussalam}

Until the foundation of the University of Brunei Darussalam in 1985, the only higher education available was English-medium teacher training. When the University opened, a conscious decision was taken to make all courses except for Malay teacher training, English-medium. Thus the courses in sociology taught in the Faculty of Administrative and Business Studies are taught in English throughout. Malay textbooks are a possible though rarely an actual tool for teacher trainees studying educational sociology. Any Malay-medium research will almost certainly be written up in English and thus there is almost no current need for Malay sociological discourse.

\section{Agents of Terminological Creation and Discourse Diffusion}

\section{Indonesia}

Until the Japanese invasion of 1942 Dutch was the medium of higher education in Indonesia. The Japanese decreed that Indonesian should become the vehicle of education with Japanese as the only foreign language and thus gave a strong impetus to the creation of Indonesian terminology and discourse. When independence was first declared in 1945 Indonesian was decreed the national language, but Dutch continued to be used in universities controlled by the Netherlands colonial authorities from 1945-49. Following the departure of the Dutch, the national vehicle of instruction became Indonesian. A body was created to support the development of the national language, in turn the Language Institute, the National Centre for Language Development and the National Centre for Language Development and Cultivation. As part of its programme of terminology development the Institute did make an attempt in 1965 to draw up a list of accepted sociological terms, but these were never published. Since 1975 the primary role of the Centre has been to develop basic language tools - a grammar and a general dictionary - and carry 
out research on the many regional languages. It also gives advice on terminology and language use and has been extremely active in language cultivation, and training and upgrading terminologists and other specialist staff. However, restricted funds and a vast terrain to cover have inevitably meant that the commissioning and publication of academic and specialist dictionaries, translations and textbooks have been left almost entirely to the private sector.

\section{Maloysia}

Until independence in 1957 higher education was English-medium. Provision for Malay to become the national language was included in the 1957 Independence Constitution and a period of ten years was decreed for the gradual replacement of English by Malay. A knowledge of Malay became a prerequisite for government employment. The National University was Malay-medium from its foundation in 1970 and education in other ethnic languages was not permitted. All higher education would be Malay-medium by 1983. A National Language and Literature Bureau was established in 1956. With far greater resources than the Indonesian Centre, the Malaysian Bureau has been extremely active in developing specialist terminology, compiling specialist dictionaries and commissioning and publishing translations. It has to date created more than 600,000 terms. Several problems have, however, limited the Bureau's success. Firstly, the dominant role of English in the production of advanced knowledge has resulted in pressure to provide English-medium education in certain subjects. Secondly, the inability to provide sufficient Malay translations or original Malay texts in higher education through lack of qualified translators has led to an inevitable dependence on English and American textbooks. Thirdly, regular exposure to English through the media and other sources has led to a continued seepage of English terms into user Malay, nullifying or greatly reducing the effect of terminological and discourse cultivation (Hsia, 1989).

\section{Brunei Darussalam}

When Brunei gained internal independence in 1959 it was decided to make Malay the national language and language of government. A National Language and Literature Bureau was set up in 1961 and has produced a small but steady stream of glossaries and dictionaries. 
However, the 1985 decision that all education, other than Malay language and Islamic religion, should be taught in English at all levels has rendered the Bureau's role ambiguous. It continues to publish and take part in MABBIM sessions, but has no obvious user for its products. Since Standard Malay is regarded as the official language of Brunei, Malaysian Bureau materials are widely available for anyone who needs them and there is little call for Brunei-specific materials. Unlike Indonesia, Brunei has not found it necessary to assign specific roles to Malay and English and young educated Bruneians have little reason to acquire specialist discourse in Malay. While the Bureau has responsibility for commissioning and arranging publication of translations into Malay, there is no obvious target readership and thus such translations serve little apparent purpose.

\section{MABBIM}

MABBIM (the Malaysia, Indonesia Brunei Darussalam Council) is a coordinating body which meets at regular intervals to standardise language use for the three Malay-speaking countries, principally in the area of terminology. It publishes a large glossary of agreed technical terms at regular intervals $(46,885$ terms in the 1992 edition), which is used to some extent, e.g. by the Brunei government staff training body, to establish and cultivate language use. Standardisation is constrained by the rules for terminological formation for each country which allow the use of indigenous vernaculars as a source of new terms. Malaysia is more inclined to draw on Arabic roots, Indonesia is fond of Javanese sources, while Brunei occasionally suggests an indigenous Brunei Malay term. Malaysia also seems more inclined to aim at linguistic purity, while Indonesia has been prone to accept naturalised ${ }^{2}$ lexis - Indonesianised transcriptions of English terms. This has minimal implications for the social sciences, since higher education follows separate paths in the three countries and the few available textbooks in Malay or Indonesian do not normally find their way into the respective universities. Indeed, until quite recently, Malaysian books were not allowed into Indonesia, and even now Indonesian books are rarely found in Bruneian or Malaysian academic

\footnotetext{
${ }^{2}$ Newmark's term. See Newmark, P. 1988, p. 82.
} 
bookshops. The language of Malaysian and Indonesian textbooks differs considerably and students in one country do not understand textbooks produced in another easily. Indeed, Malaysia has felt compelled to "translate" at least one Indonesian academic text from Indonesian into Malay.

\section{Creating Terminology}

\section{Indonesia}

The creation of new terminology has been governed since 1975 by the Pedoman Umum Pembentukan Istilah (General Guide to Term Formation) published by the National Centre for Language Development and Cultivation, a 41 -page booklet which covers basic concepts, sources of terms, grammatical aspects of terminology (including morphology), semantic aspects of terminology, abbreviations and spelling. In Part I, a term is described as a word or combination of words which accurately express the meaning of a concept, process, state or special quality in a specific field. Part II details the sources from which new terms may be drawn - from Indonesian, from languages of the same family as Indonesian e.g. Javanese and Sundanese, and from foreign languages. Foreign words may be used if they are more exact because of their connotation, if they are shorter, if their international form facilitates international transfer needs (of knowledge), or if a possible Indonesian equivalent has too many synonyms. Since Javanese is the mother tongue of the major part of the population, it is natural that many new terms should have been drawn from Javanese. Terms were taken from Dutch in the past, but English is now the major source of new terminology, particularly in modern fields of knowledge.

\section{Malaysia}

The creation of new terminology has been governed since 1975 by the Pedoman Umum Pembentukan Istilah Bahasa Malaysia (General Guide to Malaysian Term Formation) published by the National Language and Literature Bureau, a 38-page booklet which covers basic concepts, sources of terms, grammatical aspects of terminology (including morphology), semantic aspects of terminology, abbreviations and spelling. In Part I, a term is also described as a word or combination of 
words which accurately express the meaning of a concept, process, state or special quality in a specific field. Part II details the sources from which new terms may be drawn - from Malay, from Malay dialects, from Classical Malay, from languages of the same family as Malay e.g. Iban and Sundanese, and from foreign languages, principally international English. As is the case in Indonesia, foreign words may be used, and for the same reasons. Malaysia has adopted more terms from Arabic than has Indonesia.

\section{Brunei Darussalam}

The creation of new terminology has been governed since 1990 by the Pedoman Umum Pembentukan Istilah Bahasa Melayu (General Guide to Malay Language Term Formation) published by the National Language and Literature Bureau, a 43-page booklet which covers basic concepts, sources of terms, grammatical aspects of terminology (including morphology), semantic aspects of terminology, abbreviations and spelling. In Part I, a term is likewise described as a word or combination of words which accurately express the meaning of a concept, process, state or special quality in a specific field. Part II details the sources from which new terms may be drawn - from Malay, from Malay dialects, from Classical Malay, from languages of the same family as Malay e.g. Iban and Banjar, and from foreign languages. Here, as in Indonesia and Malaysia, foreign words are allowed in some situations. Since the national language of Brunei Darussalam is Standard Malay, the choice of new terms generally follows Malaysian practice, except where Malaysian terms would cause confusion or embarrassment.

\section{Translating Sociological Texts}

\section{The Dynamics of Choice}

There are almost no translations into Indonesian or Malay of major theoretical works which could illustrate the processes of sociological thinking and theory construction. If an attempt were to be made to translate a truly representative selection of works on sociological theory and practice, the available translators would be overwhelmed by the wealth of material and theoretical variety. However, what has happened in practice in Indonesia and Malaysia is that only a few selected texts have 
been translated, principally by academic specialists trained in specific (mainly American, British and, lately, Australian) schools and institutions with their own theoretical orientations. The same specialists have also begun to write textbooks in their national languages. Thus a study of translations and target language (TL) discourse can only be focused on a relatively limited number of general sociology texts. In consequence, serious questions must arise regarding the availability of theoretical and conceptual discourse and terminology for the sociological analysis of the TL societies.

\section{Syntax and Style}

Immense changes have been wrought in Indonesian and Malay syntax and style through the need to handle modern concepts, and as a result there can often be problems in identifying the interface between acceptability and incomprehensibility. On the one hand, Indonesian and Malaysian students are criticised for their inability to write adequately in the national language; on the other hand, there have been constant student (and staff) complaints that the language of many of the translations used in higher education is incomprehensible by reason of structure and style. Brunei students find academic texts in Indonesian or Malay particularly difficult because their studies are English-medium and there are no local Malay translations of English language textbooks available.

The close enmeshing of knowledge transfer via Dutch and English and the development of Indonesian and Malay has made it relatively easy to produce TL text from English SL text. However, because Classical Malay syntax on which both modern Indonesian and Modern Malay syntax are based was relatively simple, the more complex sentence patterns in TL translations derived from SL texts often pose problems of comprehension and use. It is relatively easy to convert the sentence patterns of academic English into Indonesian or Malay equivalents, but a 'formal' ${ }^{13}$ TL rendering of a SL text may encounter a "hollow frontier" of incomprehensibility.

${ }^{3}$ See Hatim, B. and Mason, I. (1990). Discourse and the Translator, (London, Longman, 1990), p. 7. 
The difficulty in establishing acceptable TL sociological texts in Indonesian or Malay is caused by a number of factors. Firstly, translation of sociological texts is often translation from a no-man's land into virgin, uncharted territory, since there is effectively no solid, established corps of specialist translators or readers of sociological material in Indonesia or Malaysia permitting to reach an agreed analysis of the SL text or an evaluation of the TL text. Wallenstein is relevant here :

In order to translate a (sociological) concept well, the translator must know (a) the degree to which any concept is in fact shared (and by whom), both at the time of writing and at the time of translating, and (b) the variations of sharing-communities in each of the two languages. The translator should also be able to infer the author's perception of the degree of sharing - that is, whether or not he is aware of or willing to acknowledge the legitimacy of debate over the concept itself. (Wallenstein, 1981, p 88)

Secondly, the translators themselves have often been more at ease in the source language (SL) than the target language (TL), and therefore often find a formally-equivalent text quite acceptable, since they sense, often unconsciously, the SL text between the lines of the TL text. Many well-educated Indonesians, especially those who obtained their qualifications abroad, are more at home with English than Indonesian syntax (Moeliono, 1981, p. 121). Likewise many elite Malaysians are still oriented towards English because they believe it is more modern and developmental than Malay (Ahmad, 1990, pp. 7-8). Moreover, the university teachers who took part in the conversion from English-medium to Malay-medium courses in higher education in Malaysia in the 1980s had originally taught in English and did not find the changeover especially easy (Hassan, 1987, p. 195). Thirdly, in Indonesia in particular, there has been a division between conservative linguists who wish to preserve the Malay character of the language and modernisers who are flexible in their attitude to the acceptance of Dutch and English syntactical patterns into Indonesian (Anwar, 1980, pp. 115-117). Fourthly, there are almost no national language academic social science journals, which means that there can be no comprehensive reviews of translated texts and no in-depth specialist dialogue on the adequacy of the TL discourse. Fifthly, while most Indonesian and Malaysian intellectuals are aware of the pengindo-saksonan (Indo-saxonisation) of their national languages, 
the national language bodies have yet to publish comprehensive guides to stylistic usage $e^{4}$ or discourse norms for specialist registers which might limit the infection. The creation of an Indonesian or Malay sociological discourse community remains dependent on the random efforts of a small and overworked cadre of academics, officials and research workers.

\section{Naturalisation and Terminological Drift}

Several of the factors mentioned above almost certainly account for the phenomenon of terminological drift. While terminologists have, from the early days of term creation, generally favoured terms derived from Indonesian and Malay, naturalisations from English now dominate dictionaries and glossaries. Indonesian and Malay morphology is insidiously open to naturalisation of English terms, creating a synergy of incomprehension in the transfer of sociological knowledge.

The term sociology itself is an example of drift. At the outset Indonesia had decided that sociology would be translated as ilmu masyarakat (from Arabic) = the science of society, while Malaysia had chosen kaji masyarakat (from Arabic) = the study of society, on the basis that -ology could be translated as either ilmu or kaji. By 1985, however, the Malaysian National Bureau's glossary of sociological terms for higher education was entitled Istilah Sosiologi Pengajian Tinggi though the term sosiologi itself does not appear among the beadwords, while Soekanto's 1983 Indonesian dictionary of sociology is labelled Kamus Sosiologi and translates sociology as sosiologi. Likewise, early attempts to find semantic and morphological equivalents for -ism e.g. by finding an equivalent meaning in the TL e.g. socialism = faham faham sosialis, or by morphological change individualism $=$ keindividuan have given way to naturalisations $-i s m a$, then -isme e.g. socialism $=$ sosialisme, empiricism $=$ empirisme ${ }^{5}$. Where full indigenisation is attempted other problems can

${ }^{4}$ Ainon Muhammad is one of the few authors to have addressed this problem in any detail in her translator's manual Panduan Terjemahan (1987, pp. 169-170).

${ }^{5}$ The same factor did of course arise when modemising knowledge was moving between Western societies and between Western societies and East Asia, but it would seem that in the former case the common cultural and linguistic heritage and extent of transtation made the comprehension of naturalised terms relatively 
arise. For example, the use of affixes may vary between Indonesian and Malay : Soekanto gives keterasingan for alienation; the Malaysian National Language and Literature Bureau, pengasingan (asing = foreign, alien). Indonesian scholars follow the Indonesian Guide in using Javanese/Sanskrit roots e.g. self-image is citra diri for Soekanto, but $i m e j$ diri in the National Language and Literature Bureau dictionary. Soekanto gives kepribadian for personality; the National Language and Literature Bureal, personaliti. Though both dictionaries contain some terms created from national language or vernacular roots, analysis of their contents as a whole shows that the terminological guides' recommendations to adopt English terms have become standard practice in both countries. The drift towards naturalisation is also evident in translated texts and, since there are as yet no dictionaries with conceptual definitions, Indonesian and Malaysian students of sociology are at a considerable disadvantage in internalising sociological knowledge.

\section{Conclusion}

The problem of creating adequate social science discourse in Malay or Indonesian is very much a phenomenon of the 20th century information society. The explosion and fragmentation of social science knowledge has made it impossible for there ever to be enough translators to create a solid body of knowledge in Malay or Indonesian remotely comparable to that available in English. Easy access to knowledge in English through the various media, in particular the development of the information superhighway, together with the constant pressure on Bruneian, Indonesian and Malaysian academics and researchers to make use of English to acquire modern knowledge have reduced the need for Indonesian or Malay translations of social science texts to a minimum. Meanwhile, the dominant role of English is reinforced through increasing naturalisation in social science terminology creation. Though the national language bodies will continue to produce and record equivalent TL terms, they are unlikely ever to have the resources to cultivate national language

simple e.g. empiricism - der Empirismus (Ger.), yilèdèçi (Russ.), while morphology barred naturalisations in the latter e.g. empiricism = jingyan zhuyi (Chin.) (jingyan = experience, zhuyi = -ism), kinh nghiUm luth (Viet.) (kinh nghi $\grave{U}_{m}=$ experience, $l u \hat{I}=$ discussion; generally - ism $=$ chò $n g h Y a$ and is used in e.g. despotism - chò nghYa chuyón chO). 
social science discourses to match the richness of writing on social science themes in English. Given the obscurity, opacity and redundancy of much sociological writing in English, this is perhaps no bad thing for the intellectual and social health of these nations. However, the increasing dependency on English for knowledge transmission does raise important questions regarding the role of the translator in the creation and cultivation of specialised registers in the national languages of the Malay world.

Canterbury, England

\section{References}

AHMAD, I. (1990). "Perancangan Bahasa dan Pembinaan Ilmu (Pengalaman Yang Lalu Dan Cabaran Masa Depan)". Jurnal Dewan Bahasa, 34, 1, pp. 4-16.

ANWAR, K. (1980). Indonesian : The Development and Use of a National Language. Yogyakarta, Gadjah Mada University Press.

BOLINGER, D. (1980). Language - The Loaded Weapon. London, Longman.

ELDRIDGE, J. (1980). Recent British Sociology. London, Macmillan.

DEWAN BAHASA DAN PUSTAKA (1985). Istilah Sosiologi Pengajian Tinggi. Kuala Lumpur.

EMMET, D. and MACINTYRE, A. (1970). Sociological Theory and Philosophical Analysis. London, Macmillan.

EVERS, H.-D. (1983). Social Science Teaching and Research in Indonesia Unpublished.

GADDIS, M. R. (ed.) (1981). Translation Spectrum. Albany, State University of New York Press. 
GEERTZ, C. (1971). A Program for the Stimulation of the Social Sciences in Indonesia. The Institute for Advanced Study, Princeton.

GIDDENS, A. (1979). Central Problems in Sacial Theory. London, Macmillan. (1989). Sociology. Cambridge (England), Polity Press.

GOULD, J. (1963). "The Vocabulary of Sociology". British Journal of Sociology, 14, 1, pp. 29-40.

HASSAN, A. (1987). Isu-isu Perancangan Bahasa : Pengintelektualan Bahasa. Malaysia, Kuala Lumpur, Dewan Bahasa dan Pustaka.

HATIM, B. and MASON, I. (1990). Discourse and the Translator. London, Longman.

HSIA, C. H. L. (1989). The Influence of English on the Lexical Expansion of Bahasa Malaysia. Kuala Lumpur, Dewan Bahasa dan Pustaka.

JOHNSON, T, DANDEKER, C and ASHWORTH, C. (1984). The Structure of Social Theory. London, Macmillan.

LACHENMEYER, C. (1971). The Language of Saciology. New York, Columbia University Press.

LEPENIES, W. (1988). Between Literature and Science : The Rise of Sociology, Cambridge (England), Cambridge University Press.

MALO, M. (ed.) (1989). Pengembangan llmu-ilmu Sosial di Indonesia Sampai Dekade '80-an. Jakarta. Indonesia, Rajawali Press.

MAYNTZ, R., HOLM, K. and HUEBNER, R. (1976). Introduction to Empirical Sociology. Harmondsworth, Penguin.

MOELIONO, A. (1981). Pengembangan dan Pembinaan Bahasa. Jakarta, Penerbit Jambatan. 
MUHAMMAD, A. (1987) Panduan Terjemahan. Kuala Lumpur, Dewan Bahasa dan Pustaka.

NEWMARK, P. (1988). A Textbook of Translation. London, Prentice Hall.

SARTORI, G., RIGGS, F.W. and TEUNE, H. (1975). Tower of Babel. On the Definition and Analysis of Concepts in the Social Sciences. Pittsburgh, University of Pittsburgh.

SCHUTZ, A. (1970). "Concept and Theory Formulation in the Social Sciences". Sociological Theory and Philosophical Analysis. London, Macmillan.

SOEKANTO, S. (1983). Kamus Sosiologi. Jakarta, CV. Rajawali.

WALLENSTEIN, I. (1981). "Concepts in the Social Sciences". Translation Spectrum. Albany, State University of New York Press, p. 88.

WORSLEY, P. (1970). Introducing Sociology. Harmondsworth, Penguin.

WRIGHT, S. E. and STREHLOW, R. A. (1993). Standardizing and Harmonizing Terminology : Theory and Practice. Philadelphia, ASTM.

RÉSUMế : Apports de la traduction au discours sociologique au Nusantara - La sociologie connaît une croissance rapide en tant que discipline académique et instrument de développement national dans les nations de langue malaise de l'Asie du Sud-Est : le Brunei Darussalam, l'Indonésie et la Malaisie. Les particularités de la terminologie et du discours sociologiques posent des problèmes spécifiques pour les traducteurs de textes sociologiques, qui ont été à l'avant-garde des créations linguistiques en raison de l'usage croissant de manuels en langue nationale.

En Indonésie, où les études supérieures sont, depuis l'indépendance, conduites en indonésien, les premiers textes sociologiques furent traduits du hollandais. Cependant, après le départ des Hollandais, un soutien américain majeur à l'enseignement de la sociologie de la part des États-Unis, a donné lieu, depuis les années 60, à une 
nouvelle vague de textes traduits cette fois-ci de l'anglais. En Malaisie, le choix du malais comme langue d'enseignement universitaire a suscité le besoin de traduire les mots-clés anglais. Au Brunei Darussalam, si l'enseignement universitaire se fait en anglais, les étudiants de langue malaise ont ressenti la nécessité de traduire les documents sociologiques pour réussir dans leur apprentissage.

Bien que ces trois pays se soient accordés pour standardiser la terminologie et la morphologie, le langage sociologique est dans une certaine mesure devenu divergent. Pendant ce temps, la pénurie de traducteurs qualifés empêche la production suffisante et adéquate de traductions.

Cet article aborde (1) les notions de atransparencex et «d'invisibilité» dans l'élaboration de textes cibles en langue indonésienne et malaise ainsi que (2) la possibilité de adomestiquer» les concepts et méthodologies et de fournir des textes cibles qui puissent être utilisés tant pour les études que pour la recherche.

\section{ABSTRACT : Translation as a Provider of Models of Sociological} Discourse in Nusantara - The social sciences have seen rapid growth both as academic subjects and as instruments of national development in the Malay language nations of SE Asia: Brunei Darussalam, Indonesia and Malaysia. The particular nature of social science terminology and discourse has presented special problems for translators of social science texts, who have been at the frontiers of language creation as national language texts have been increasingly used at all levels of education in Indonesia and Malaysia.

In Indonesia, where higher education had been Indonesian-medium after independence, the first social science texts to be translated were from Dutch, but, following the departure of the Dutch, extensive American support to social science education by the USA from the 1960s led to a new wave of texts translated from English. In Malaysia the decision to introduce Malay-medium higher education created a need for translations of key texts from English. In Brunei Darussalam, while higher education is English-medium, Malay-medium university students have found it necessary to translate English social science material to succeed in their learning.

While the three countries have an agreement to standardise terminology and discourse, social science language has to some extent diverged. Meanwhile a serious shortage of qualified translators has 
hampered the production of adequate and sufficient translations.

This paper discusses (1) the issues of "transparency" and "invisibility" in providing Indonesian and Malay target texts and (2) the feasibility of "domesticating" concepts and methodologies and providing recipient language texts which are usable and developmental.

Brian D. Smith : 29 Nackington Road, Canterbury, Kent CTI 3NU England. 